American Journal of Applied Sciences 4 (12): 1045-1053, 2007

ISSN 1546-9239

(C) 2007 Science Publications

\title{
Business Cycle Synchronization Between Australia and New Zealand
}

\author{
${ }^{1}$ Jie Wei, ${ }^{2}$ Minsoo Lee, and ${ }^{3}$ Christopher Gan \\ ${ }^{1}$ Zeroipo Ltd., Beijing, China, \\ ${ }^{2}$ Shenzhen Graduate School of Business, Peking University Campus \\ University Town in Shenzhen, Xili, Nanshan District, Shenzhen, PRC \\ ${ }^{3}$ Commerce Division, PO Box 84,Lincoln University, Canterbury, New Zealand
}

\begin{abstract}
There has been a high degree of economic and financial integration between Australia and New Zealand with free trade agreements linking the capital and labor markets. Given a strong economic relationship, business-cycle transmission is expected to exist between the two countries. By analyzing the shock-transmission channels via trade, monetary policy, and exchange rates between Australia and New Zealand we can infer that if Australia and New Zealand trade less, have more similar monetary policy structure, or have less similar economic structures they would have stronger economy correlation. The results also show that the highly integrated banking system between Australia and New Zealand is an additional avenue for shock transmission between both countries.
\end{abstract}

Keywords: Shock transmission channels; Business cycle; Monetary policy; Exchange rate pass-through

\section{INTRODUCTION}

Business-cycle synchronization across two economies might be caused by the endogenous shock transmission between the two countries or by common exogenous influences. For example, the economic prosperity from 1960 through 1973 in Japan caused the mineral boom during the same period in Australia, because Japan needed the agricultural goods and mineral resources imported from Australia to accommodate this expansion ${ }^{[39]}$. This is an example of endogenous shock transmission that results in synchronization across economies. Similarly, when a common shock impacts two countries at the same time, the two countries might also be synchronized. For example, the oil shock in 1973 caused both Japan and Australia to fall into recession.

Australia and New Zealand are interdependent on each other and share many economic and financial similarities. There has been a high degree of economic integration between Australia and New Zealand via free trade agreements including linked capital and labor markets. Australia is New Zealand's largest trading partner; however, New Zealand is only ranked the sixth in the list of Australian trading partners. Australia traded significantly with Japan and the US. On 18 May
2004, Australia and the US signed the Australia-United States Free Trade Agreement (AUFTA). This resulted in imbalanced trade relation and may have influence the New Zealand economy to some extent since there is no free trade agreement between New Zealand and the US. For example, Australian sheep meat exporters would have advantages over New Zealand sheep exporters in the US market.

Australia and New Zealand are small open economies trading extensively with the rest of the world and the floating currency exposes two economies to exchange rate fluctuations through external trade. Exchange rate pass-through (ERPT) is the phenomenon that changes in the value of foreign currencies are reflected in changes in import prices ${ }^{[16]}{ }^{[5]}$ pointed that how much exchange rate changes can be passed through into import prices or be absorbed in exporter profit margins or markups is the core question of exchange-rate-pass-through study.

Bilateral exchange rate between Australia and New Zealand and New Zealand's import prices in bilateral trade with Australia moved in the same direction but the magnitude of fluctuations in the import prices is less than the degree of exchange rate changes, which showed that the ERPT in New Zealand is not complete and Australian exporters did partially pass exchange 
rate fluctuations into New Zealand import prices. Compared to Mexico and other emerging economy, the degrees of ERPT in New Zealand and Australia are much lower ${ }^{[34]}$.

Australia and New Zealand monetary policy share some similarities while having some differences. New Zealand policy targets agreement between the Minister of Finance and the Governor of the Reserve Bank of New Zealand (RBNZ) is governed under section 9 of the Reserve Bank of New Zealand Act 1989. The Act shows New Zealand monetary policy has a single objective: maintaining a stable general level of prices. The policy target is to keep future consumer price index inflation rates between $1 \%$ and $3 \%$ on average over the medium term. ${ }^{[2]}$ explain that this regime has such characteristics as public announcement of quantitative inflation target and a high degree of transparency and accountability.

Before 1999, RBNZ implemented monetary policy by controlling the quantity of cash made available to settlement banks. However, the quantity of cash settlement is not closely related to interest rates, inflation rates and other economic variables. In order to implement monetary policy more efficiently, RBNZ introduced the official cash rate (OCR) as a device on 17 March 1999, which will be reviewed eight times a year ${ }^{[1]}$. The RBNZ undertakes to pay (charge) financial institutions an interest rate of $0.25 \%$ below (above) the OCR for money deposited in the Reserve Bank settlement accounts (lending overnight cash loan). Because there is no limit on the amount of cash that RBNZ lend or borrow, no commercial bank would lend (borrow) short-term loans at a rate significantly higher (below) than the OCR. Therefore, the RBNZ can influence short-term interest rates, such as the 90-day bill rate, floating mortgages ${ }^{[36]}$.

Similarly, the Reserve Bank of Australia (RBA) implemented monetary policy under section 10 (2) of Reserve Bank Act. Since 1993, Australian monetary policy target is to keep consumer price inflation between $2 \%$ and $3 \%$ on average over medium term. Unlike New Zealand, RBA implements monetary policy by setting the cash rate, which is the rate charged on overnight loans between financial intermediaries in the money market. By doing this, RBA manages the supply of funds available to banks in the money market.

Given such close economic relations, businesscycle transmission is expected to be found between these two countries but more from Australia to New Zealand than vice versa. ${ }^{[38]}$ found that macroeconomic shocks are more likely to transmit from Australia to New Zealand than from New Zealand to Australia. The authors claimed that $15.9 \%$ of the variance in New Zealand's Gross Domestic Product (GDP) was from Australia, while only $8.4 \%$ of the variance in Australian GDP was accountable by New Zealand between 1969Q1 to 1994Q1.

[19] argued that a negative shock in an economy may spill over to other countries if the countries are interdependent through international trade, foreign investment and other linkage. ${ }^{[22]}$ showed that linkages between New Zealand and Australia, in the form of trade and financial links and immigration policies, served as a propagation mechanism so that an external shock in one country would shift to another country.

Macroeconomic shock transmission is a two-edged phenomenon. A positive economy shock in one economy will be spilled over to closed economies and during recession highly correlated countries will move into bad time together. This study examines how Australian shocks propagate to the New Zealand economy through bilateral trade, exchange rate passthrough phenomenon, and monetary policy and provides policy implication for the two economies. The remainder of this paper is organised as follows. Section 2 reviews previous studies on transmission channels via trade. Section 3 describes data and the methodology employed. Results and their implications are discussed in section 4 . Section 5 provides the conclusions.

The role of trade in transmission mechanisms of international shocks is ambiguous. Some researchers claimed that trade intensity does not impact business cycle transmission. [23] employs the shares of employment in each sector of the economy to measure economy structure and demonstrated that it is the degree of similarity of economic structures rather than trade itself that caused synchronization among OECD countries. ${ }^{[9]}$ find similar results using trade intensity to examine the business cycle correlations in the AsiaPacific region.

On the contrary, ${ }^{[6,17]}$ argue that trade helps shocks propagate from one region to other regions through demand linkages because in recession the demand of an economy for imports decreases and thus leads the output in other countries to fall. The elementary trade repercussion model in ${ }^{[11]}$ indicates that macroeconomic fluctuations are more likely to be transmitted from an importing country to the country that supplies the imports unless these exporters have monopolized their positions. ${ }^{[25]}$ find the GDP growth rate correlation average is about $45 \%$ among the OECD countries over the period 1965-1990. The authors present evidence that it is the commodity trade that transmits economic fluctuations across economies and causes the high 
degree of synchronization in growth rates. Recently, ${ }^{[37]}$ compare the business cycle synchronization within currency union member countries with non-member countries of the currency union. They conclude that currency union member countries trade more and consequently are more synchronized. Similarly, ${ }^{[8]}$ note that the trade relation within States in the U.S. is closer than that within countries in European Economic Community (EEC) indicating more synchronized across States than across European countries.

[13] [26] believe that trade results in more specialization and larger differences between economies. In this case, an industry-specific shock in an economy would be less likely to be transmitted to other economies. To counter ${ }^{[13,26]}$ argument, ${ }^{[20]}$ split the trade data into intra- and inter-industry trade to test whether specialization reduces business cycle correlation among 21 countries. The authors show that specialization does not negatively affect international transmission. However, ${ }^{[40]}$ present opposing views when they investigate the output co-movements among the five East Asian countries and regions, including China, Hong Kong, Japan, Korea and Taiwan. The authors explain when trade occurs mainly across different industries, higher specialization would induce the industrial structures of the various countries to diverge, resulting in less synchronized movements of business cycles. However, ${ }^{[4]}$ claims that the shock transmission depends on which dominant force is driving the economy: demand or industry-specific shocks. If demand shocks outweigh industry-specific shocks, trade intensity helps shocks transmit to other economies. Otherwise, the more trade between countries, the less shocks would be spilled over across economies.

Exchange rate pass-through (ERPT) phenomenon may cause import prices shocks and further increase domestic inflation rates. ${ }^{[5]}$ empirically test the effects of exchange rate, exporter costs and real domestic GDP on import prices to investigate the degree of ERPT for 25 OECD countries. New Zealand's short-run and longrun ERPT are $58.2 \%$ and $76.7 \%$ during the period 1975-1999, respectively. In addition, the short-run passthrough elasticity for New Zealand in 1999 decreased to 0.39 from 0.47 in 1989 while the long-run fell to 0.53 from 0.62 in 1989. Furthermore, the authors argue that the real reason causing the decrease in ERPT level is the shift in the composition of import bundles of OECD countries because manufacturing and food products have partial pass-through rate while energy and raw material imports have nearly complete pass-through. However, ${ }^{[29]}$ examines the transmission of exchange rate fluctuations of import price in Korea comparing the level of ERPT for pre-crisis period (1980-1997) with that for post-crisis period (1997-2003) and the results show that both the short-run and long-run pass-though elasticities increase contradicting the ${ }^{[5]}$ findings.

ERPT differs across countries. For example, [15] demonstrated that foreign firms with high market share have fewer competitors and are able to shift cost shocks including exchange rate fluctuations to import prices. Their findings are similar to ${ }^{[24]}$ findings. ${ }^{[24]}$ analyzed commodity price adjustments on exchange rate changes for five agricultural commodities exported from the US to Japan. The authors find asymmetric result that an exchange rate decline (JPY/USD) was completely passed through to Japan, but an exchange rate increase was incomplete.

[14] observes the behavior of real exchange rates by analyzing the structure of international trade. Similar countries trading similar goods under two-way intraindustry trade have lower pass-through and less persistent real exchange rate because of their strong linkages in international prices. Similarly, ${ }^{[43]}$ claims that exchange rate pass-through be greater for more differentiated products.

There are several articles on monetary policy transmission within a country focusing on the domestic channels through which monetary policy affects the local economy ${ }^{[30,31}$ and ${ }^{32]}$. For example, in ObstfeldRogoff two-country model ${ }^{[33]}$, optimal monetary policy is implemented with sticky nominal prices. The authors argue that monetary and fiscal policies can lead international transmission of welfare. Their finding indicates that there is no need for the coordination of monetary policies across countries. ${ }^{[3]}$ incorporate the pricing-to-market (PTM) into Obstfeld-Rogoff model [33] and claim that welfare transmission from optimal monetary policy is dependent on firms pricing behaviors. When firms practice pricing-to-market monetary policy influences welfare transmission negatively indicating that international coordination of monetary policies is necessary.

\section{MATERIALS AND METHODS}

Macroeconomic interdependence model, shock transmission model, and ERPT analysis model are employed to empirically examine how shocks are propagated between Australia and New Zealand through bilateral trade, exchange rate pass-through phenomenon. The data consists of quarterly time series covering 66 quarters from 1986:Q1 to 2002:Q2. Appendix A provides the sources of the data set. 
Macroeconomic Interdependence Model: Macroeconomic interdependence model, a modified version from ${ }^{[38]}$, examines the impact of the Australian economy on the New Zealand economy and shows the degree of Australian shocks transmitted to New Zealand:

$Z_{t}=\delta+\sum_{i=1}^{p} \phi_{i} Z_{t-i}+\sum_{i=1}^{6} L_{O I L}+\mathcal{E}_{t}$

and $Z_{t}=\left(L Y_{N}, L C P I_{N}, B L R_{N}, O C R, L Y_{A}, L C P I_{A}, B L R_{A}\right.$, $C R, L E X C)$,

where

$L$ stands for a logarithm indicating that equation $\mathrm{I}$ is a double-log equation;

Subscript $N$ denotes New Zealand, while subscript $A$ denotes Australia;

$Y$ is GDP;

$C P I$ is consumer price index;

$B L R$ denotes bank-lending rates;

$O C R$ indicates New Zealand Official Cash Rate, while $C R$ is Australian Cash Rate;

$E X C$ is the bilateral exchange rate (NZD/AUD); and

$O I L$ stands for the world crude oil spot price, which is an exogenous variable

Business Cycle Transmission Model: Business cycle transmission equation decomposes the economic synchronization between Australia and New Zealand into three transmission channels, i.e. trade, exchange rate and monetary policy. It examines and compares the influences of these three channels on international economic correlation.

$\left|\Delta Y_{n}-\Delta Y_{a_{t}}=\alpha+\beta \max \left(\frac{\text { Trade }_{\text {nat }}}{Y_{n, t}}, \frac{\text { rade }_{a n t}}{Y_{a}}\right)+\gamma\right| O C R_{n}-\left.C R_{a}\right|_{t}+\lambda \mid E M P_{n}-E M P_{a t_{t}}+\delta L E X C_{t}+\varphi \sum_{i=1}^{6} L O L_{L_{i}}+\varepsilon_{t}$

$\left|\Delta Y_{n}-\Delta Y_{a}\right|_{t}$ is the absolute value of the difference in GDP growth rate between Australia and New Zealand, measuring the economic correlation between them. A higher economic correlation reflects that shocks are more likely to transmit across the two countries;

$\max \left(\frac{\text { Trade }_{i j}}{Y_{i}}, \frac{\text { Trade }_{j i}}{Y_{j}}\right)$ represents the trade intensity and $\left|O C R_{n}-C R_{a}\right|_{t}$ is the absolute value of the difference between New Zealand OCR and Australian $\mathrm{CR}$, measuring the similarity of monetary policy. $\left|E M P_{n}-E M P_{a}\right|_{t}$ is the absolute value of the difference in the ratio of employment numbers in tradable industry to total employment numbers between them, measuring the similarity of economy structure.
$L E X C$ is the logged value of the bilateral exchange rate (NZD/AUD) and LOIL is an exogenous variable denoting the logged value of world oil prices.

Exchange Rate Pass-Through Analysis: The ERPT analysis explains the role of bilateral exchange rates in economic shock transmission from Australia to New Zealand. According to ${ }^{[21]}$, a $10 \%$ increase (iih) New Zealand import prices would cause New Zealand consumer prices to increase by $0.5 \%$ during the first three months and by $1.5 \%$ in the long run. ${ }^{[21]}$ finding indicates that ERPT is a potential channel for exogenous shocks to impact the domestic economy, especially the inflation rate.

Equation 3 calculates the ERPT level, i.e. the degree to which bilateral exchange rate fluctuations are passed into New Zealand import prices.

$p_{t}^{m}=a+b e_{t}+c w_{t}^{e x}+d \varphi_{t}^{m}+\varepsilon_{t}$,

where

$p^{m}$ denotes New Zealand import prices;

$e$ stands for the bilateral exchange rate (NZD/AUD);

$\boldsymbol{\varphi}^{m}$ is New Zealand market demands, represented by the Index of Industrial Production (IIP);

$w^{e x}$ is Australian wage market; and b shows the longrun ERPT elasticity into New Zealand's import prices.

The estimated coefficient of $e$ shows how much exchange rate fluctuations are spilled over to New Zealand import prices. Following ${ }^{[5,28]}$, $^{\text {ex }}$ is calculated as $w^{e x}=\frac{N E E_{t}^{e x} P_{t}^{e x}}{R E E_{t}^{e x}}$, where $N E E^{e x}$ is Australian nominal effective exchange rate; $R E E^{e x}$ is Australian real effective exchange rate; and $P^{e x}$ is Australian CPI.

According to ${ }^{[28,35]}$, the first difference form of equation (3) is adopted when no cointegration relation is found among time series variables. This is shown in equation (4), where $\gamma$ represents the short-term ERPT elasticity into import prices, and $\theta=\frac{\gamma}{1-\beta}$ captures the long-term ERPT elasticity.

$$
\Delta p_{t}^{m}=\alpha+\beta \Delta p_{t-1}^{m}+\gamma \Delta e_{t}+\delta \Delta w_{t}^{e x}+\lambda \Delta \phi_{t}^{m}+\eta_{t}
$$

This study employs the Augmented-Dicky-Fuller test (ADF), cointegration test, Granger-Causality test, impulse response analysis, and variance decomposition analysis in analyzing the data. The ADF is used to test for the unit root and order of integration for all time series variables. Following this, maximal eigenvalue and trace statistic tests are used to test for cointegration 
relation among variables, respectively in each equation. If cointegration relation is found, the vector error correction model (VECM) is established to investigate the long-run equilibrium relationship among variables. Otherwise, nonstationary variables are transformed into the differenced form. The Granger-Causality test and Impulse-Response-Analysis will be tested for equations (1) and (2). Variance decomposition analysis is used to examine shock transmission in dynamic process for equation (1). In addition, the sample period is split into pre-1991 (1986Q1-1990Q4) and post-1991 (1991Q12002Q2) sub-periods to compare the level of ERPT across time based on equation (3).

\section{RESULTS AND DISCUSSION}

Long-run equilibria are found in equations (1) and (2) and thus the VECMs are estimated. For equation (3), the first difference form is used because no long-run equilibrium is found among the variables.

Macroeconomic Interdependence Model: The Johansen cointegration analysis shows that there is long run equilibrium among variables in equation (1) and the long run equilibrium found in VECM estimates is give as follows:

$$
\begin{gathered}
\mathrm{LY}_{\mathrm{N}}=1.6249+0.5244 * \mathrm{LY}_{\mathrm{A}}+1.9362 * \mathrm{LCPI}_{\mathrm{N}}- \\
0.0141 * \mathrm{BLR}_{\mathrm{N}}-0.0015 * \mathrm{OCR} \\
-1.4016 * \mathrm{LCPI}_{\mathrm{A}}-0.0090 * \mathrm{BLR}_{\mathrm{A}}+0.0105 * \mathrm{CR}- \\
0.9790 * \mathrm{LEXC}
\end{gathered}
$$

The estimated coefficient of $\mathrm{LY}_{\mathrm{A}}$ in equation (5) represents the long run elasticity of income transmission, which indicates that a one percent change in Australian GDP would cause New Zealand GDP to change by 0.52 percent change. No Granger Causality relation is found in either direction between New Zealand and Australian GDP. The result demonstrates that there is a lack of business cycle transmission between New Zealand and Australia.

According to ${ }^{[41]}$, the Impulse-Response-Analysis is the most effective method of checking for Granger noncausality. The impact of New Zealand and Australian GDP on each other is examined by the ImpulseResponse-Analysis as the impacts diffuse through the entire system. From Figures 1 and 2, one standard deviation innovations of Australian GDP caused NZ GDP to change by 0.024 units. In contrast, one standard deviation innovations of New Zealand GDP caused Australia GDP to change by 0.004 units. This indicates that Australian GDP is more likely to influence New Zealand future GDP values. Therefore, shocks are more likely to be shifted from Australia to New Zealand than otherwise.

We follow [39] approach in selecting Cholesky order of the five variables in equation (1) $\left(\mathrm{LY}_{\mathrm{N}}, \mathrm{LCPI}_{\mathrm{N}}\right.$, $\mathrm{BLR}_{\mathrm{N}}, \mathrm{OCR}$, and $\mathrm{LY}_{\mathrm{A}}$.). Tables 1 and 2 show that after eight quarters, $7.43 \%$ variance in New Zealand GDP is due to Australian GDP, while only $5.54 \%$ variance in Australian GDP is from New Zealand GDP. This finding is consistent with ${ }^{[38]}$ findings indicating that macroeconomic shocks are more likely to transmit from Australia to New Zealand than in the opposite direction.

Businesses Cycle Transmission Model: Johansen cointegration rank test result shows that there exist long run relations among the time series variables in equation (2), reflecting that the dependent variable $\left|\Delta Y_{n}-\Delta Y_{a}\right|_{t}$ is not exogenous to this system.

The long run equilibrium found in VECM estimates is shown in equation (6) below:

$$
\begin{aligned}
& \left|\Delta Y_{n}-\Delta Y_{a}\right|_{t} \quad=\quad 0.0067+\quad 0.1739 \text { * } \\
& \max \left(\frac{\text { Trade }_{i j}}{Y_{i}}, \frac{\text { Trade }_{j i}}{Y_{j}}\right) \quad+0.0012 * \\
& \left|O C R_{n}-C R_{a}\right|_{t} \\
& -0.3715 *\left|E M P_{n}-E M P_{a}\right|_{t}+0.0609 * \\
& \text { LEXC }
\end{aligned}
$$

Equation (6) shows that if New Zealand and Australia trade intensity, adopt more similar monetary policy, or have less similar economic structures, these two countries would have stronger economic correlation. In addition, equation (6) also indicates that the decreasing bilateral exchange rates strengthen the synchronization across these two countries.

The results show that trade intensity has the most significant power to influence the shock transmission from Australia to New Zealand, followed by the similarity of economic structures, the similarity of monetary policies and the bilateral exchange rates. If New Zealand and Australia trade less or have less similar economic structures, the two countries would have stronger economic correlation. This is because of 
Table 1: Variance Decomposition of $\mathrm{LY}_{\mathrm{N}}$ (in percentage terms)

\begin{tabular}{llllllllll}
\hline \multirow{2}{*}{ Due to } & \multicolumn{2}{l}{ Quarters Since Shock } & & & & & & & \\
& 1 & 4 & 8 & 12 & 16 & 20 & 40 & 60 & 66 \\
\hline $\mathrm{LY}_{\mathrm{N}}$ & 100 & 92.70 & 91.94 & 91.97 & 92.07 & 92.19 & 92.54 & 92.69 & 92.72 \\
$\mathrm{LY}_{\mathrm{A}}$ & 0.00 & 6.66 & 7.43 & 7.42 & 7.32 & 7.21 & 6.86 & 6.71 & 6.68 \\
\hline
\end{tabular}

Table 2: Variance Decomposition of $\mathrm{LY}_{\mathrm{A}}$ (in percentage terms)

\begin{tabular}{|c|c|c|c|c|c|c|c|c|c|}
\hline \multirow{2}{*}{ Due to } & \multicolumn{9}{|c|}{ Quarters Since Shock } \\
\hline & 1 & 4 & 8 & 12 & 16 & 20 & 40 & 60 & 66 \\
\hline $\mathrm{LY}_{\mathrm{N}}$ & 0.57 & 5.01 & 5.54 & 5.80 & 5.97 & 6.10 & 6.44 & 6.60 & 6.59 \\
\hline $\mathrm{LY}_{\mathrm{A}}$ & 93.95 & 83.12 & 81.43 & 80.78 & 80.39 & 80.12 & 79.47 & 79.23 & 79.18 \\
\hline
\end{tabular}

Table 3: Estimation for ERPT Elasticity

\begin{tabular}{llllll}
\multicolumn{2}{l}{$\begin{array}{l}\text { Full Sample Pass-Through Elasticity } \\
\text { 1986:Q1-2002:Q2 }\end{array}$} & $\begin{array}{l}\text { Pre 1991 } \\
\text { Elasticity }\end{array}$ & Period & Pass-Through & \multicolumn{2}{l}{$\begin{array}{l}\text { Post-1991 Period Pass-Through Elasticity } \\
\text { 1986:Q1-1990:Q4 }\end{array}$} & & 1991:Q1-2002:Q2 & \\
Short-Term & Long-Term & Short-Term & Long-Term & Short-Term & Long-Term \\
\hline \multirow{2}{*}{0.7092} & 0.7769 & 0.8620 & 0.7647 & 0.5800 & 0.8187 \\
& & & & & \\
\end{tabular}

the wide difference in economy structures between New Zealand and Australia, which causes the two economies to be specialized in different industries. Therefore, the bilateral trade between New Zealand and Australia gets more and more concentrated in interindustry trade. A shock within a specific industry thus would be less likely transmitted across these two countries. Furthermore, similar monetary policies would also make the New Zealand and Australian economies closer because they can provide similar economic conditions stimulating the two economies to grow in similar pattern. An exchange rate (NZD/AUD) decrease strengthens the shock transmission across the two countries. The reason is that Australian exporters have high market share in New Zealand, and therefore they are able to raise products price when NZD appreciates while maintaining prices the same (or reduce prices by a small proportion).

The statistical results for Granger-Causality test on equation (2) indicating that all independent variables do not Granger cause the economic correlation between New Zealand and Australia $\left(\left|\Delta Y_{n}-\Delta Y_{a}\right|_{t}\right)$. The lack of Granger-Causality relationship between $\left|\Delta Y_{n}-\Delta Y_{a}\right|_{t}$ and four endogenous variables is implausible given there is a cointegration relationship found among them ${ }^{[18]}$.

The Impulse-Response-Analysis is conducted on the economic correlation $\left(\left|\Delta Y_{n}-\Delta Y_{a}\right|_{t}\right)$, trade intensity ( $\max \left(\frac{\text { Trade }_{i j}}{Y_{i}}, \frac{\text { Trade }_{j i}}{Y_{j}}\right)$ ), the similarity of monetary policies $\left(\left|O C R_{n}-C R_{a}\right|_{t}\right)$, the similarity of economy structures $\left(\left|E M P_{n}-E M P_{a}\right|_{t}\right)$ and the bilateral exchange rates (LEXC). The result is plotted in Figure 3, where GDP represents $\left|\Delta Y_{n}-\Delta Y_{a}\right|_{t}$, TRADE stands for $\max \left(\frac{\text { Trade }_{i j}}{Y_{i}}, \frac{\text { Trade }_{j i}}{Y_{j}}\right)$, SPREADS are $\left|O C R_{n}-C R_{a}\right|_{t}$ and ECON denotes $\left|E M P_{n}-E M P_{a}\right|_{t}$

From Figure 3, it is evident that the economic correlation between New Zealand and Australia positively responds to one standard deviation shocks in trade intensity, the similarity of monetary policies and the bilateral exchange rates while negatively to the similarity of economic structures. In addition, the trade intensity has the most significant power to influence the economic correlation between New Zealand and Australia, followed by the similarity of economic structures, the similarity of monetary policies and the bilateral exchange rates. 


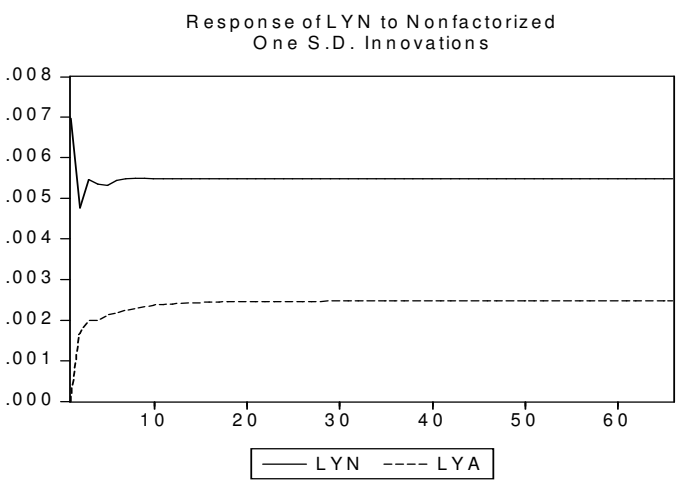

Fig. 1: Response of $\mathrm{LY}_{\mathrm{N}}$ to Non-factorized One Standard Deviation Innovations of $\mathrm{LY}_{\mathrm{N}}$ and $\mathrm{LY}_{\mathrm{A}}$

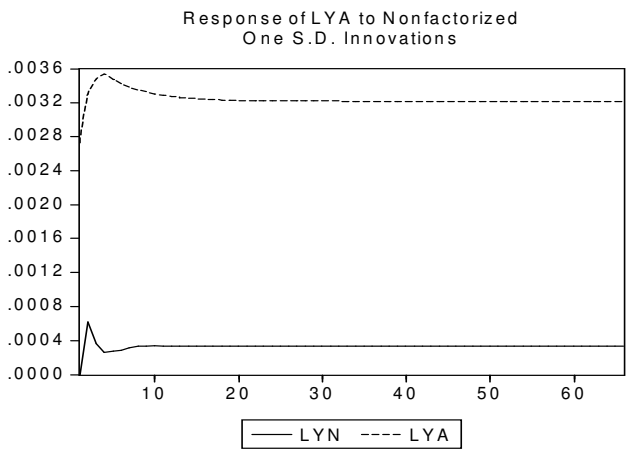

Fig. 2: Response of $\mathrm{LY}_{\mathrm{A}}$ to Non-factorized One Standard Deviation Innovations of $\mathrm{LY}_{\mathrm{N}}$ and $\mathrm{LY}_{\mathrm{A}}$

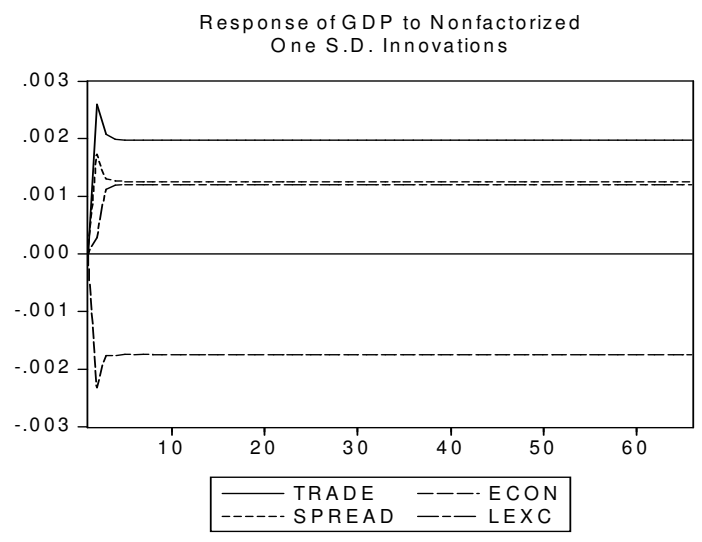

Fig. 3: Response of $\left|\Delta Y_{n}-\Delta Y_{a}\right|_{t}$ to $\max \left(\frac{\text { Trade }_{i j}}{Y_{i}}, \frac{\text { Trade }_{j i}}{Y_{j}}\right),\left|O C R_{n}-C R_{a}\right|_{t}$, $\left|E M P_{n}-E M P_{a}\right|_{t}$ and LEXC
Exchange Rate Pass-Through Analysis: Cointegration relation does not exist in this case. In order to compare the ERPT level between pre-1991 and post-1991, full sample period is divided into pre-1991 sample period and post-1991 sample period. In equation (4), $\gamma$ represents the shortgterm ERPT elasticity into import prices, and $\theta=\frac{}{}$ catches the long-term ERPT elasticity. ERPT ellasti $\beta$ ties for different sample periods are calculated and reported in Table 3 .

From Table 3, it is shown that Australian exporters passed-through most exchange rate fluctuations into New Zealand import price, about $71 \%$ in the short run and $77.69 \%$ in the long run. This shows that the ERPT level in New Zealand is between zero and $100 \%$, which is similar ${ }^{[5,28,43]}$ findings. The calculated ERPT level is solely from Australia. It is higher than the average short-run and long-run ERPT elasticities from the rest of the world to New Zealand during the period 19751999 , which are $58.2 \%$ and $76.7 \%$ respectively ${ }^{[5]}$. The high ERPT level can be partially explained by the fact that a great portion of New Zealand imported products from Australia are energy and raw material, which have nearly $100 \%$ pass-through elasticities ${ }^{[5]}$.

For the full sample period (1986:Q1-2002:Q2) and the post-91 sample period (1991:Q1-2002:Q2), longterm ERPT elasticity is higher than short-term elasticity. This is consistent with ${ }^{[5,28]}$ findings. In contrast, for the pre-91 sample period (1986:Q1-1990: Q4), the short-term ERPT elasticity is higher than long-term ERPT elasticity, contradicting ${ }^{[28]}$ findings. This is due to the significantly higher inflation rates before 1990 compared to that after 1990, because the short-run ERPT elasticity is significantly influenced by inflation environment ${ }^{[5,7,42]}$.

Furthermore, the short-term ERPT elasticity decreased dramatically, which is consistent with [5] finding but contradicts ${ }^{[28]}$ findings. On the other hand, the long-term ERPT elasticity increased slightly, which is consistent with ${ }^{[28]}$ findings but contradicts [5] findings. ${ }^{[5,7,42]}$ noted that besides the inflation rate, nominal exchange rate volatility also impacts ERPT level, especially the short run ERPT. Therefore, the combined force of exchange rate volatility and inflation rates drives the changes in ERPT level. The volatilities of bilateral exchange rate (NZD/AUD) are 0.0821 (1986:Q1-2002:Q2), 0.0788 (1986:Q2-1990:Q4), and 0.0823 (1991:Q1-2002:Q2). It is clear that the bilateral exchange rate became more volatile during the post-91 sample period. According to ${ }^{[5,7,42]}$, more volatile exchange rate should result in higher ERPT. The shortrun ERPT elasticity is influenced more by inflation rate, compared to the volatility of the bilateral exchange rate. The long run ERPT elasticity, on the other hand, is more driven by the force of exchange rate volatility rather than inflation rate.

\section{CONCLUSIONS}

This paper systematically analyses the shocktransmission channels, including trade, monetary policy, 
and exchange rates, from Australia to New Zealand over the period 1986:Q1 to 2002:Q2. The results showed that if New Zealand and Australia trade less, have more similar monetary policies, have less similar economic structures or have smaller exchange rate differences (NZD/AUD), these two countries would have stronger economy correlation. The highly integrated banking systems of Australia and New Zealand are additional avenue for shock transmission between these two countries.

The findings of this paper reflect the importance of international coordination of monetary policies suggesting RBA takes the impact of Australian economy on New Zealand economy into account especially when they adopt policies that would lead the AUD to depreciate. This study also predicts that New Zealand and Australia would have closer economic correlation after the establishment of AUFTA.

New Zealand relies more on Australia in bilateral trade and Australian banks dominate the New Zealand banking market. In addition, the results are also consistent with ${ }^{[38]}$ findings, which claimed that $15.9 \%$ of the variance in New Zealand's GDP is from Australia, while only $8.4 \%$ of the variance in Australian GDP is accountable by New Zealand during the period 1969:Q1 to 1994:Q1.

Trade intensity has the most significant power to influence the shock transmission from Australia to New Zealand, followed by the similarity of economic structures, the similarity of monetary policies and the bilateral exchange rates. In addition, if New Zealand and Australia trade less or have less similar economic structures, these two countries would have stronger economic correlation. Wide differences in economy structures between New Zealand and Australia cause these two economies to be specialized in different industries. Therefore, the bilateral trade between New Zealand and Australia gets more and more concentrated in inter-industry trade. An industry-specific shock thus would be less likely transmitted across these two countries. More similar monetary policies would also make New Zealand and Australia economies to grow in similar patterns.

An appreciation of New Zealand currency would strengthen the shock transmission across these two countries because Australian exporters have high market share in New Zealand. This finding further demonstrates that the floating exchange rate regime cannot ensure completely that New Zealand can get rid of external economy shocks ${ }^{\text {[see } 10,12 \text {, and } 27] \text {. }}$

The long-term ERPT elasticity is higher than shortterm elasticity for the full sample period (1986:Q12002:Q2) and the post-91 sample period (1991:Q12002:Q2). This is identical with ${ }^{[5]}$ and ${ }^{[28]}$ findings. However, for the pre-91 sample period (1986:Q11990:Q4), this study finds that the short-term ERPT elasticity is higher than long-term ERPT elasticity, contradicting ${ }^{[5 \text { and } 28]}$ findings. The possible explanation is that the short-run ERPT level in New Zealand is more subject to the inflation environment.

\section{REFERENCES}

1. Archer D., A. Brookes, M. Reddell., 1999. A Cash Rate System for Implementing Monetary Policy. Reserve Bank of New Zealand Bulletin, 62 (1): 51 61.

2. Bernanke, B.S., T. Laubach, F.S. Mishkin, A.S. Posen, 2001. Inflation Targeting: Lessons from the International Experience. Princeton University Press.

3. Betts C., M.B. Devereux, 2000. International Monetary Policy Coordination and Competitive Depreciation: A Re-Evaluation. Journal of Money, Credit and Banking, 32 (4): 722-745.

4. Calderon C.A., A.E. Chong, E.H. Stein, 2002. Trade Intensity and Business Cycle Synchronization: Are Developing Counties Any Different?. Paper presented at the IPES Seminars at the IADB.

5. Campa J.M., L.S. Goldberg, 2002. Exchange Rate Pass-Through into Import Prices: A Macro or Micro Phenomenon. NBER Working Paper, National Bureau of Economic Research, USA, No. 8934.

6. Canova F., H. Dellas, 1993. Trade Interdependence and International Business Cycle. Journal of International Economics, 34: 23-49.

7. Choudhri E., D.S. Hakura, 2001. Exchange Rate Pass-Through to Domestic Prices: Does the Inflationary Environment Matter?. International Monetary Fund Working Paper.

8. Clark T., E. van Wincoop, 2001. Borders and Business Cycles. Journal of International Economics, 55: 59-86.

9. Crosby M., 2003. Business Cycle Correlations in Asia-Pacific. Working Paper, University of Melbourne, Melbourne, Australia.

10. Devereux M.B., C. Engel, 1998. Fixed versus Floating Exchange Rates: How Price Setting Affects the Optimal Choice of Exchange-Rate Regime. NBER Working paper, National Bureau of Economic Research, USA, No. 6867.

11. Dornbusch R., 1980. Open Economy Macroeconomics. New York: Basic Books.

12. Dornbush, R., 1983. Flexible Exchange Rates and Interdependence. International Monetary Fund, Staff Papers, 30: 3-30.

13. Eichengreen B., 1992. Is Europe An Optimum Currency Area? In: The European Community After 1992: Perspectives from the Outside. (eds. H. Grubel, S, Borner) pp. 138-161. Macmillan, England.

14. Faruqee, H., 1996. Real Exchange Rates and the Pattern of Trade: Comparative Dynamics for North and South. Journal of International Money and Finance. 15 (2): 313-336.

15. Feenstra R., J. Gagnon, M. Knetter, 1993. Market Share and Exchange Rate Pass-Through in World Automobile Trade. NBER Working Paper, National Bureau of Economic Research, USA, No.8934. 
16. Fisher E., 1989. A Model of Exchange Rate PassThrough. Journal of International Economics, 26: 119-138.

17. Frankel J., R. Rose, 1998. The Endogeneity of the Optimal Currency Area Criterion. Economic Journal, 108: 1009-1025.

18. Granger C. W.J., 1988. Some Recent Development in a Concept of Causality. Journal of Econometrics, 39: 199-211.

19. Glick R., A.K. Rose, 1999. Contagion and Trade: Why are Currency Crises Regional?. Journal of International Money and Finance, 18 (4): 603-617.

20. Gruben W.C., J. Koo, E. Millis, 2002. How Much Does International Trade Affect Business Cycle Synchronization? Working Paper, Federal Reserve Bank of Dallas, No. 203.

21. Hampton T., 2001. How Much Do Import Price Shocks Matter for Consumer Prices?. Reserve Bank of New Zealand Discussion Paper Series, DP 2001/06.

22. Hull L., 2002. Foreign-Owned Banks: Implications for New Zealand's Financial Stability. Reserve Bank of New Zealand Discussion Paper Series, DP2002/05.

23. Imbs J., 2000. Sectors and the OECD Business Cycle. CEPR Discussion Paper, No. 2473.

24. Jabara C.L., N.E. Schwartz, 1987. Exchange Rates and Commodity Prices. American Journal of Agricultural Economics, 69: 580-590.

25. Kraay A., J. Ventura, 1995. Trade and Fluctuations. Working Papers, Agriculture, Land, Commodity Prices, Markets, No.1560.

26. Krugman P., 1993. Lessons of Massachusetts for EMU, In: Adjustment and Growth in the European Monetary Union. (eds. F. Torres, F.Giavazzi) pp. 241-261. Cambridge University Press.

27. Lastrapes W.D., F. Koray, 1990. International Transmission of Aggregate Shocks under Fixed and Flexible Exchange Rate Regimes: United Kingdom, France, and Germany, 1959 to 1985. Journal of International Money and Finance, 9: 402-423.

28. Lee M., 2005. Asian Financial Crisis and Exchange Rate Pass-Though in Korea. Review of Applied Economics, 1 (1): 37-51.

29. Lee M., 2004. Exchange Rate Pass-Though and Transmission of Monetary Policy between Korea and its Major Trading Partners. KAREC Discussion Paper, Korea-Australasia Research Center, Australia, 5 (6).

30. Meltzer A.H., 1995. Monetary, Credit and Other Transmission Processes: A Monetarist Perspective. Journal of Economic Perspectives, 9 (4): 49-72.
31. Mishkin F.S., 1995. Symposium on the Monetary Transmission Mechanism. Journal of Economic Perspectives, 9 (4): 3-10.

32. Mishkin F.S., 2001. The Monetary Transmission Mechanism in the Euro Area: More Evidence from VAR Analysis. European Central Bank Working Paper Series, No. 91.

33. Obstfeld M., K. Rogoff, 1995. Exchange Rate Dynamics Redux. Journal of Political Economy, 103: 624-660.

34. Ortiz G., 1999. How Should Monetary Policy Makers React to the New Challenges of Global Economic Integration: The Case of Mexico? Symposium of Global Economic Integration: Opportunities and Challenges, Federal Reserve Bank of Kansas City, Kansas, USA.

35. Otani A., S. Shigenori, S. Toyoichiro, 2003. The Decline in the Exchange Rate Pass-Through: Evidence from Japanese Import Prices. Monetary and Economic Studies, Bank of Japan, 21 (3): 5381.

36. Reserve Bank of New Zealand, 2002. What is the Official Cash Rate? Downloadable at http://www.rbnz.govt.nz/monpol/about/0072140.ht ml.

37. Rose A., C. Engel., 2000. Currency Unions and International Integration. NBER Working Paper, National Bureau of Economic Research, USA, No. 7872.

38. Selover D.D., D.K. Round, 1995. Business Cycle Transmission between Australia and New Zealand: A Vector Autoregression Approach. Australian Economic Papers, 34 (65): 218-243.

39. Selover D.D., D.K. Round, 1996. Business Cycle Transmission and Interdependence between Japan and Australia. Journal of Asian Economics, 7 (4): 569-602.

40. Shin K., Y. Wang, 2004. Trade Integration and Business Cycle Co-Movements: The Case of Korea with Other Asian Countries. Japan and the World Economy, 16: 213-230.

41. Sims C.A., 1980. Macroeconomics and Reality. Econometrica, 48 (1): 1-48.

42. Taylor J., 2000. Low Inflation, Pass-Through, and the Pricing Power of Firms. European Economic Review, 44: 1389-1408.

43. Yang J., 1996. Exchange Rate Changes and Pricing Behavior of US Exporter. Review of International Economics, 4 (3): 339-354. 